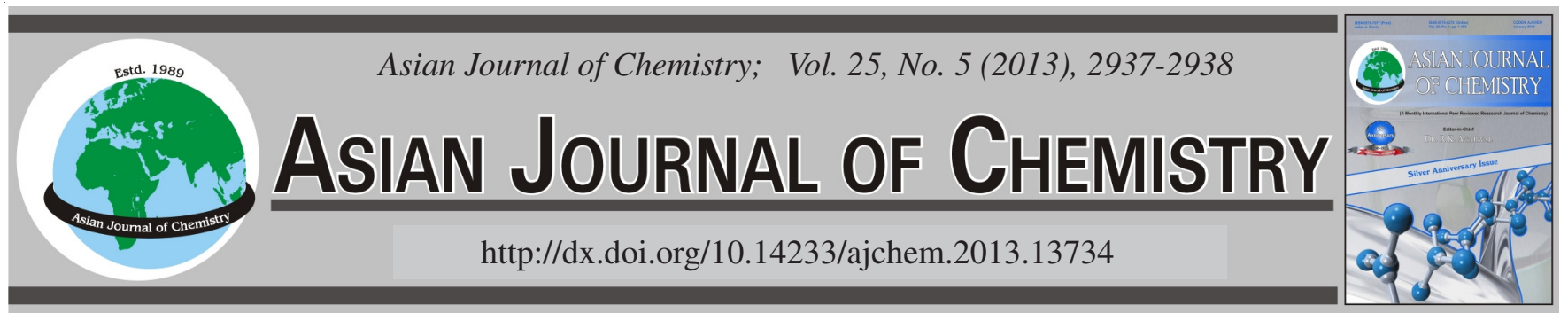

NOTE

\title{
Using of $\mathrm{ZnCl}_{2} / \mathrm{AlCl}_{3}-\mathrm{SiO}_{2}$ Catalyzed for One-Pot and Tree Substituted Synthesis of 1,4- Dihydropyridine Derivatives Via Hantzsch Reaction
}

\author{
Mohammad R. Asghariganjeh ${ }^{*}$ and Parastoo Nasirveise
}

Department of chemistry, Omidiyeh Branch, Islamic Azad University, Omidiyeh, Iran

*Corresponding author: Fax: + 98652 3231035; Tel: +98 652 3231035; E-mail: mohammadreza.asghari@ yahoo.com

In this study, we utilize $\mathrm{ZnCl}_{2} / \mathrm{AlCl}_{3}-\mathrm{SiO}_{2}$ as a moderate, retrievable, cost-effective and available catalyst at room ambient temperature and in the solvent free in order to synthesize 1,4-dihydropyridine, which entails biological characteristics in Hantzsch reaction. This reaction is as a result of compression of three components, in the solvents free and high yield products and with high-efficiency and purity.

Key Words: Hantzsch reaction, Multi-component reaction, One-pot synthesis, Solvent free.

Di-hydropyridines have been recognized as the largest and most important calcium passage controllers ${ }^{1-3}$. Research has expanded chemistry of di-hydropyridines. These compounds reduce blood pressure and also cause imbalance of coral and vessel cells. As a result, these compounds have the property of antiblood-pressure ${ }^{4-7}$. Other different medicines are utilized for treating forgetfulness, diabetes and also removing tumors ${ }^{8-10}$. The importance of di-hydropyridines is not only restricted to the medicine effects because they conduct important activities in some other live systems. Oxidation and reduction, which are crucial bio-processes, are examples in whose structures the di-hydropyridines act as the main core by virtue of enzymes ${ }^{11-14}$.

Regarding the items presented in relation to green chemistry reactions, multi-component Hantzsch different medical properties of compounds with core of 1,4,di-hydropyridines, generalization and expansion of these reactions could be so important ${ }^{15-18}$. The design of molecules which are of importance economically or environmentally, is normally found in the series of these reactions ${ }^{19-21}$. One of the most important methods to synthesize derivatives of 1,4 di-hydropyridines, multicomponent and single-stage compression of these compounds is by virtue of Hantesh reaction. Various catalysts have been applied for these types of reactions. Some of these reactions are so interesting in terms of chemical synthesis ${ }^{22-26}$. Most of the cited reactions are expensive, complex and not retrievable. Therefore, in this study a simple method has been proposed for three-component and single stage synthesis of derivaties of 1,4-dihydropyridines in the solvent free and at ambient temperature and with the presence of a new catalyst, $\mathrm{ZnCl}_{2}$ /
$\mathrm{AlCl}_{3}-\mathrm{SiO}_{2}$, which does not have the drawbacks of other catalysts.

Melting points were measured on the electrothermal 9100 apparatus and are uncorrected. IR spectra were measured on a Bomen FT-IR-MB 100 spectrometer. ${ }^{1} \mathrm{H}$ and ${ }^{13} \mathrm{C}$ NMR spectra were measured with a Bruker DRX-300 avance spectrometer at 300 and 75. MHz using TMS as internal standard. Chemical shifts are reported (d) relative to TMS and coupling constant $(\mathrm{J})$ is reported in hertz $(\mathrm{Hz})$. Mass spectra were recorded on a Shimadzu QP 1100 EX mass spectrometer. Elemental analysis for $\mathrm{C}, \mathrm{H}$ and $\mathrm{N}$ were performed using a heraus $\mathrm{CHN}$ rapid analyzer.

In order to synthesize the derivatives of 1,4-dihydropyridines in a corked test tube, $1 \mathrm{mmol}$ of dimedon, $1 \mathrm{mmol}$ ethyl acetoacetate or methyl acetoacetate, $1.2 \mathrm{mmol}$ aluminium acetate, $1 \mathrm{mmol}$ aromatic aldehyde and $0.2 \mathrm{mmol}$ catalyst $\mathrm{ZnCl} / \mathrm{AlCl}_{3}-\mathrm{SiO}_{2}$ are added and mixed for the required time and the progress of the experiment was followed by thin layer chromatography (TLC) (Tank solvent $n$-hexane and ethyl acetate with the ratio of 1:2). After completion of reaction, ethyl acetate was added to the obtained product for catalyst removal (Scheme-I). After heating the yielded product was filtered. In this way, after cooling the solution under the filter, the prospective product was re-crystalized with ethyl acetate.

\section{Spectral data:}

Methyl-1,4,5,6,7,8-hexahydro-2,7,7-trimethyl-4(naphthalen-2-yl)-5-oxoquinoline-3-carboxylate (l): m.p. $280{ }^{\circ} \mathrm{C}$, IR (KBr, $\left.v_{\max }, \mathrm{cm}^{-1}\right): 3282(\mathrm{NH}) ;{ }^{1} \mathrm{H}$ NMR (DMSO) 
TABLE-1

PHYSICAL CHARACTERISTIC DATA OF THE SYNTHESIZED 1,4-DIHYDROPYRIDINE DERIVATIVES

\begin{tabular}{|c|c|c|c|c|c|c|c|}
\hline Entry & $\mathrm{Ar}$ & $\mathrm{R}$ & Products & Time (h) & Yield (\%) & m.p. $\left({ }^{\circ} \mathrm{C}\right)$ & Lit. m.p. $\left({ }^{\circ} \mathrm{C}\right)$ \\
\hline 1 & $\mathrm{Ph}$ & $\mathrm{CH}_{3}-\mathrm{CH}_{2}$ & $\mathrm{a}$ & 3 & 95 & 189 & $190^{8}$ \\
\hline 2 & 4- $\mathrm{MeC}_{6} \mathrm{H}_{4}$ & $\mathrm{CH}_{3}-\mathrm{CH}_{2}$ & b & 2.45 & 90 & 270 & $270^{8}$ \\
\hline 3 & 4- $\mathrm{MeOC}_{6} \mathrm{H}_{4}$ & $\mathrm{CH}_{3}-\mathrm{CH}_{2}$ & $\mathrm{c}$ & 2.5 & 90 & 255 & $256^{8}$ \\
\hline 4 & $4-\mathrm{ClC}_{6} \mathrm{H}_{4}$ & $\mathrm{CH}_{3}-\mathrm{CH}_{2}$ & d & 2.5 & 92 & 244 & $243^{9}$ \\
\hline 5 & $4-\mathrm{NO}_{2} \mathrm{C}_{6} \mathrm{H}_{4}$ & $\mathrm{CH}_{3}-\mathrm{CH}_{2}$ & e & 2.5 & 93 & 242 & $243^{9}$ \\
\hline 6 & $4-\mathrm{MeO} \mathrm{C}{ }_{6} \mathrm{H}_{4}$ & $\mathrm{CH}_{3}-\mathrm{CH}_{2}$ & $\mathrm{f}$ & 2.5 & 90 & 255 & $256^{9}$ \\
\hline 7 & $2-\mathrm{ClC}_{6} \mathrm{H}_{4}$ & $\mathrm{CH}_{3}-\mathrm{CH}_{2}$ & $\mathrm{~g}$ & 2.5 & 94 & 207 & $206-208^{15}$ \\
\hline 8 & $3-\mathrm{NO}_{2} \mathrm{C}_{6} \mathrm{H}_{4}$ & $\mathrm{CH}_{3}-\mathrm{CH}_{2}$ & $\mathrm{~h}$ & 2.5 & 91 & 218 & $218-220^{15}$ \\
\hline 9 & $4-\mathrm{BrC}_{6} \mathrm{H}_{4}$ & $\mathrm{CH}_{3}-\mathrm{CH}_{2}$ & $\mathrm{i}$ & 2.5 & 92 & 252 & $252-253^{15}$ \\
\hline 10 & 2-Furyl & $\mathrm{CH}_{3}-\mathrm{CH}_{2}$ & $\mathrm{j}$ & 2.5 & 90 & 247 & $246-248^{15}$ \\
\hline 11 & $4-\mathrm{OHC}_{6} \mathrm{H}_{4}$ & $\mathrm{CH}_{3}-\mathrm{CH}_{2}$ & $\mathrm{k}$ & 2.45 & 89 & 232 & $231-232^{15}$ \\
\hline 12 & 2-naphthyl & $\mathrm{CH}_{3}$ & 1 & 2.5 & 90 & 280 & - \\
\hline 13 & $3-\mathrm{Cl} \mathrm{C}{ }_{6} \mathrm{H}_{4}$ & $\mathrm{CH}_{3}$ & $\mathrm{~m}$ & 2.5 & 92 & 220 & - \\
\hline
\end{tabular}

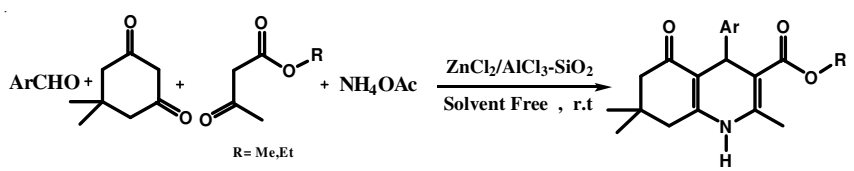

Scheme-I: Synthesis of 1,4-dihydropyrydine derivatives via Hantzsch reaction by simple and efficient method under solvent free and room themprature condenstions

$\delta_{\mathrm{H}}: 0.80\left(3 \mathrm{H}, \mathrm{s}, \mathrm{CH}_{3}\right), 0.99\left(3 \mathrm{H}, \mathrm{s}, \mathrm{CH}_{3}\right), 2.07(2 \mathrm{H}, \mathrm{dd}, J=$ $\left.67.4 \mathrm{~Hz}, J=15.8 \mathrm{~Hz}, \mathrm{CH}_{2}\right), 2.33\left(3 \mathrm{H}, \mathrm{s}, \mathrm{CH}_{3}\right), 2.4\left(2 \mathrm{H}, \mathrm{dd}_{\text {broad }}\right.$, $\left.J=23.2 \mathrm{~Hz}, \mathrm{CH}_{2}\right), 3.51\left(3 \mathrm{H}, \mathrm{s}, \mathrm{OCH}_{3}\right), 5.05(\mathrm{H}, \mathrm{s}, \mathrm{CH}), 7.37-$ 7.80 (7H, m, Arom); ${ }^{13} \mathrm{C}$ NMR (DMSO, $\left.300 \mathrm{MHz}\right) \delta_{\mathrm{C}}: 18.84$, 26.77, 29.62, 32.59, 36.45, 50.67, 51.17, 103.49, 110.28, $125.56,125.64,126.23,127.06,127.71,127.89$, 128.11, 132.10, 133.27, 145.34, 145.99, 150.16, 167.81, 194.89; MS $(\mathrm{m} / \mathrm{z}, \%): 375\left(\mathrm{M}^{+}\right)$.

Methyl-4-(3-chlorophenyl)-1,4,5,6,7,8-hexahydro2,7,7-trimethyl-5-oxoquinoline-3-carboxylate (m): m.p. $220^{\circ} \mathrm{C}$, IR (KBr, $\left.v_{\max }, \mathrm{cm}^{-1}\right): 3201(\mathrm{NH}), 1710$ (CO), 1608 (CO broad); ${ }^{1} \mathrm{H}$ NMR (DMSO) $\delta_{\mathrm{H}}: 0.82\left(3 \mathrm{H}, \mathrm{s}, \mathrm{CH}_{3}\right), 0.99$ $\left(3 \mathrm{H}, \mathrm{s}, \mathrm{CH}_{3}\right), 2.08\left(2 \mathrm{H}, \mathrm{dd}, J=56.6 \mathrm{~Hz}, J=16.1 \mathrm{~Hz}, \mathrm{CH}_{2}\right)$, $2.30\left(3 \mathrm{H}, \mathrm{s}, \mathrm{CH}_{3}\right), 2.32\left(2 \mathrm{H}, \mathrm{dd}_{\text {broad }}, J=17.103 \mathrm{~Hz}, \mathrm{CH}_{2}\right), 3.52$ $\left(3 \mathrm{H}, \mathrm{s}, \mathrm{OCH}_{3}\right), 4.85(\mathrm{H}, \mathrm{s}, \mathrm{CH}), 7.08-7.25(4 \mathrm{H}, \mathrm{m}$, Arom $) ;{ }^{13} \mathrm{C}$ NMR (DMSO) $\delta_{\mathrm{C}}: 18.82,26.75,29.52,32.63,36.21,50.55$, 51.25, 102.98, 109.91, 126.24, 126.44, 127.54, 130.30, 132.87, $146.38,150.22,150.32,167.57,194.85 ; \mathrm{MS}(\mathrm{m} / \mathrm{z}, \%): 359$ $\left(\mathrm{M}^{+}\right)$.

A simple and effective method for a three-component and one-pot 1,4,di-hydropyridines derivatives from concentrations of dimedon, aromatic aldehyde, ethyle aceto acetate or methle aceto acetate and ammonium acetate in presence of low amount of $\mathrm{ZnCl}_{2} / \mathrm{AlCl}_{3}-\mathrm{SiO}_{2}$ catalyst in conditions without solvent and ambient temperature is used. The physical characteristic data of the synthesized 1,4-dihydropyridine derivatives are given in Table-1. A new catalyst is used that omit the disadvantages of several other catalysts such as complexity, high costs, toxicity and no recoverability. Several similar reactions are done in toxic solvents whereas in this project the reaction is done in the absence of solvent.

\section{ACKNOWLEDGEMENTS}

The authors acknowledged the financial support from the Research Council of Islamic Azad University, Omidiyeh Branch.

\section{REFERENCES}

1. V. Sridharan, P.T. Perumal, C. Avendano and J.C. Menendez, Tetrahedron, 63, 4407 (2007).

2. C.O. Kappe, Molecules, 1, 3 (1998).

3. M. Maheswara, V. Siddaiah, G.L.V. Damu and C.V. Rao, ARKIVOC, 201 (2006).

4. R.K. Vohra, C. Bruneau and J.L. Renauda, Adv. Synth.: Catal., 348, 2571 (2006).

5. D.M. Stout and A.I. Meyers, Chem. Rev., 82, 223 (1982).

6. A. Domling and I. Ugi, Angew. Chem. Int. Engl., 39, 3321 (2000).

7. G.R. Green, J.M. Evans and A.K. Vong, in eds.: A.R. Katrizky, C.W. Rees and E.F.V. Seriven, Incomprehensive Heterocyclic Chemistry II; Pergamon Press: Oxford, Vol. 5, p. 469 (1995).

8. M.M. Kumor and R.A. Maurya, Tetrahedron. Lett., 48, 3887 (2007).

9. M.M. Heravi, K. Bakhtiari, N.M. Javadi, F.F. Bamoharram, M. Saeedi, H.A. Oskooie, J. Mol. Catal. A, 50, 264 (2007).

10. A. Kumar and R.A. Maurya, Tetrahedron Lett., 48, 3887 (2007).

11. C. Cai, M. Hung and B.Y. Wen. J. Fluorine Chem., 131, 111, (2010).

12. J.L. Donelson, R.A. Gibbs and S.K. De, J. Mol. Catal. A, 256, 309 (2006).

13. A. Heydari, S. Khaksar, M. Tajbakhsh and H.R. Bijanzade, J. Fluorine Chem., 130, 609 (2009).

14. A. Kumar and R.A. Maurya, Tetrahedron, 63, 1946 (2007).

15. S.B. Sapcal, K.F. Shelk, B.B. Shigate and M.S. Shingare, Tetrahedron Lett., 50, 1754 (2009).

16. S. Ko, M.N.V. Sastry, C.C. Lia and C.-F. Yao, Tetrahedron Lett., 46, 5771 (2005).

17. Shengkai Ko and Ching-Fa Yao, Tetrahedron, 62, 7293 (2006).

18. A.S. Kumar and S. Mujumdar, J. Mol. Catal. A, 35, 269 (2007).

19. F. Alonso, P. Riente and M. Yus, Tetrahedron, 64, 1847 (2008).

20. F. Alonso, P. Riente and M. Yus, Tetrahedron Lett., 49, 1939 (2008).

21. F. Alonso, P. Riente and M. Yus, Synlett, 1289 (2008).

22. A. Dhakshinamoorty and K. Pitchumani, Tetrahedron Lett., 49, 1818 (2008).

23. L. Zank and J. Zielinski, J. Appl. Catal. A, 268, 334 (2008).

24. M. Li, Z. Zuo, L. Wen and S. Wang, J. Comb. Chem., 10, 436 (2008).

25. C.S. Reddy and M. Ragha, Chin. Chem. Lett., 19, 775 (2008).

26. S.R. Cherkupally and R. Mekalan, Chem. Pharm. Bull., 56, 1002 (2008). 